\title{
Semantic Functions of Passive Constructions in the Holy Qur'an
}

\author{
Khalil Hassan Nofal \\ Department of English/Language Centre, Philadelphia University, Jordan
}

\begin{abstract}
This study seeks to give a comparative account of passive constructions in terms of semantic functions in the Holy Qur'an where they are widely used in its chapters and verses. . A comparison and contrast is indirectly made between what grammarians stated in their books and the cases found in the Holy Qur'an. This is to identify the functions stated by the grammarians and not mentioned in the Holy Qur'an and those found in the Holy Qur'an but not stated by the grammarians. This situation highlights an essential need to have Arabic revised in the light of investigation of the Holy Qur'an as it has been revealed in the straight Arab tongue.
\end{abstract}

Index Terms - brevity, instructions, prohibition, permission, confirmation, suspense, versification, assonance, thematization, presupposition

\section{INTRODUCTION}

The active or passive turn is used according as our viewpoint is shifted from one primary to another in the sentence. Active and passive sentences mean essentially the same, yet they are not exactly synonymous. It is therefore redundant for a language to have both turns. As a rule, the person or thing that is the centre of interest at the moment is made the subject (or the theme) of the sentence, and therefore the verb must in some cases be put in the active, in others in the passive.

Most grammar books, if not all, contain lists of functions of passive. The corpus (The Holy Qur'an) revealed that in the vast majority of cases the choice of passive turn is due to one of the following: (i) goal prominence, (ii) agent (actor) prominence, (iii) constructing agentless (short) sentence i.e concealing or de-emphasizing the agent, (iv) elaboration on the agent, (v) retaining the same grammatical subject in successive sentences, (vi) more suitable in complex sentences, and (vii) producing suspense. See (Jespersen (1933) and (1951), Thompson (1960), Palmer (1965), Halliday (1967), Corray (1967), Huddleston (1971) and (1984), Quirk et. al (1972) and (1985) Leech and Svartvik (1975), Allen (1983), Celce - Murcia et.al. (1983) Van Ek (1984) Palmer (1987)

Generally speaking, passive sentences in Arabic are basically used when the agent participant (actor) of the action is unknown, or when the writer/speaker intentionally chooses not to name the agent. Consequently, great emphasis is placed on the action and the goal (or the patient). See Al- Ashmoni (1955), Ibn Ya'sh, Ibn Agil (1972), Hasan (1975), Ibn Hisham (1979), Ibn Usfour (1980), Al- Samarra'i (1989) Al- Mallah (1988) Khalil (1989), Maghalseh (2007) among others.

\section{SEMANTIC FunCtions}

In the Holy Qur'an, the agent is omitted and the passive is used for one of the following reasons: (i) unknown agent, (ii) explicit agent, (iii) implicit agent, (iv) interest in goal / action, (v) concealment or de-emphasizing of the identify of the agent, and (vi) suspense, among others:

1. Passive constructions are used for brevity and conciseness through the ellipsis of the agent participant (actor).

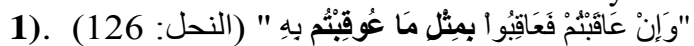

"And if ye punish, let your punishment be propartionate to the wrong that has been done to you". (Al- Nahl: 126).

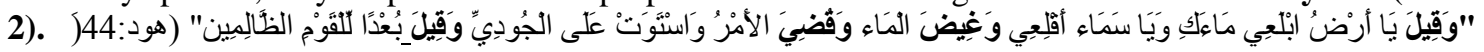

"Then the word went forth: "O earth! swallow up thy water, and O sky! withhold (thy rain)!" And the water abated, and the matter was ended. The Ark rested on Mount Jūdi and the word went forth: "Away with those who do wrong". (Hūd: 44)

The rhetorical advantage of passivization is achieved through brevity and conciseness because it intensively affects the recipient as the attention is focused on the process rather than the details. See (Al- Siyuti: Al-Itgan fi ?ulum AlQur'an, Vol. 3, P. 170).

The sayer of the first past passive verb (قيل) in verse (2) above is the Almighty Allah, whereas the sayer of the second past passive verb is either the Almighty Allah when he means cursing and evicting tyrants, or the Prophet Nūh when he means supplicating Allah to curse / evict tyrants. See (Al- Razi: Mafatih Al- Ghaib Vol. 8, P. 539). Moreover, all the passive verb forms are used to indicate the excellence and perfection of the system and symmetry used. See (Ibn AlJawziyyah: Al Fawā?id Al- Mushawwiqa ?ilā `ulūm Al- Qur'an, P. 264-65). 
2. Passive is used when Allah instructs man about matters related to their dealings with one another as illustrated in the following verses:

3).

"When a (courteous) greeting is offered to you, meet it with a greeting still more courteous, or (at least) of equal courtesy". (Al-Nisā': 86)

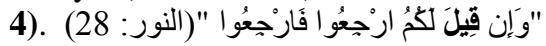

"If you are asked to go back, go back" (Al- Nūr: 28)

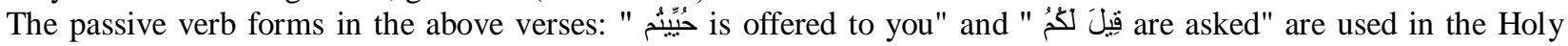
Qur'an as they are dealings among people.

3. Passive is also used to show Allah's orders / commands and directives or instructions:

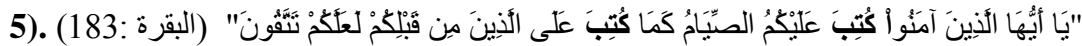

"O ye who believe! Fasting is prescribed to you as it was prescribed to those before you, that you may (learn) self restraint". (Al- Baqara: 183)

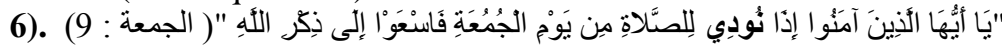

"O ye who believe ! When the call is proclaimed to prayer on Friday (The Day of Assembly), hasten earnestly to the remembrance of Allah". (AL-Jumu? a: 9)

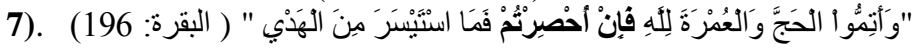

"And complete the Hajj or Umra in the service of Allah, but if ye are prevented (from completing it), send an offering for sacrifice". (Al- Baqara: 196)

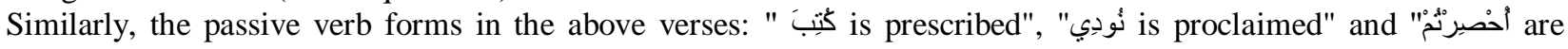
prevented" are passivized as they are all instructions from the Almighty Allah to people.

4. Passivization is also used when the focus is on permission and prohibition:

The verb "احلِّل is / are permitted" in the following verses is passivized as it is permission from Allah to people to allow them perform certain actions that are not prohibited.

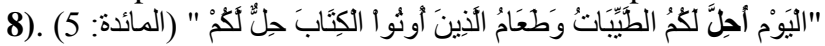

"This day are (all) things good and pure made lawful unto you. The food of the people of the book is lawful unto you". (Al- Ma?ida : 5).

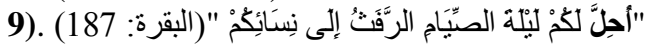

"Permitted to you on the night of the fasts, is the approach to your wives". (Al-Baqara: 187)

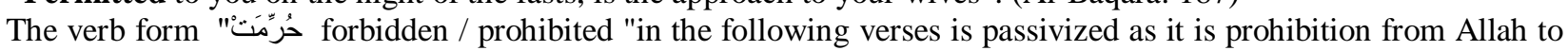
all people.

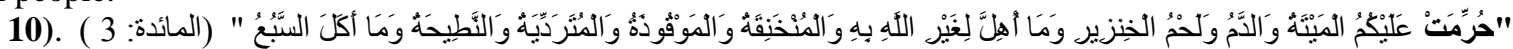

"Forbidden to you (for food) are: dead meat, blood, the flesh of swine, and that on which hath been invoked the name of other than Allah, that which hath been killed by strangling or by a violent blow, or by headlong fall." (Al-ma? ida: 3)

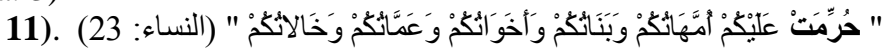

"Prohibited to you (for marriage) are: your mother's, daughters, sisters; father's sisters, mothers sister "(Al- Nisā?: 23)

5. When indicating humbleness, as Prophet Yusuf did when he interpreted the dream to his colleagues in prison:

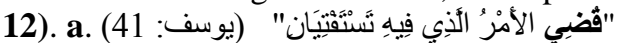

"(So) hath been decreed that matter whereof ye twain do enquire". (Yusuf: 41)

and he did not say

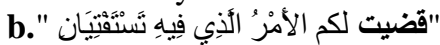

"I decreed that matter whereof ye twain do enquire"

politely and humbly

6. Verification and confirmation:

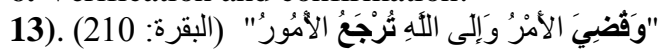

"And the question is (thus) settled? But to Allah do all questions go back (for decision)". (AL-Baqara: 210)

The past passive verb form "قضي" "is settled" is used to show verification and confirmation. This is to say, this verb indicates what this verse includes will occur for sure. See (Al- Shawkani: Fath Al- Qadir Vol. 1, P. 313).

7. The passive is also used to glorify or dignity the agent participant, in this case the Almighty Allah:

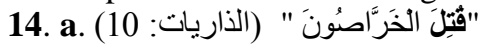

"Cursed be the conjecturers". (Al- Zāriyāt: 10)

instead of saying

b. "قتل الهه الخر اصون

"Allah cursed the conjecturers".

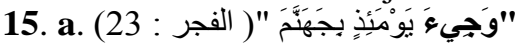

"And Hell, that Day, is brought (face to face)". (Al- Fajr: 23)

instead of saying

b. "وجاء الله يومئذٍ بجهنم" 
"And Allah that Day brought Hel"1. (face to face).

8. Explicit Agent: The passive is used when the agent (the Almighty Allah) is already known and there is no need to mention Him. That is to say, the agent can be easily recovered from the linguistic / situational context:

16). "خُلِقَ الإنسَانُ مِنْ عَجَلِ" (الأنبياء: 37)

"Man is a creature of haste" (Al- Anbiyā'?: 37)

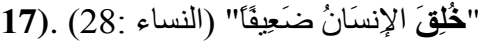

"For man was created weak (in resolution)" (Al-Nisā?: 28)

The rhetorical advantage of the passive verb in (16) is verification / confirmation, whereas it is ratification / approval in (17).

The agent does not exist in these two verses, and the action (process) is concentrated on. See (Ibn Jinny: Al Muhtasib Vol. 1, P. 66). "If the verb is passivized, this is not because the agent is implicit, but to know that the process actually takes place". See (Al- Zarkashi: Al- Burhan Vol. 3 ,P. 144). In the following verses, the passive verbs are used to concentrate on the process, but not on the agent.

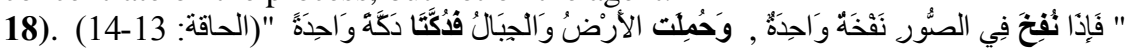

"Then, when one blast is sounded on the Trumpet, and the earth is moved and its mountains, and they are crushed at one stroke". (Al- Hāqqa: 13-14)

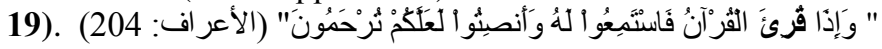

"When the Qur'an is read, listen to it with attention, and hold your peace: that ye may receive Mercy ". (Al- A?rāf: 204)

9. The passive is used to create suspense in the Holy Qur'an, particularly in story telling .See (Al- Samarra'i ,1980, p.96-7).

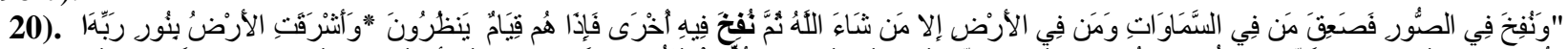

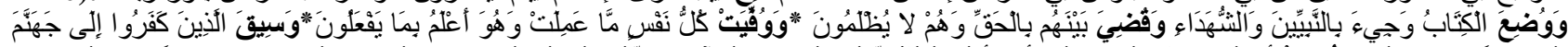

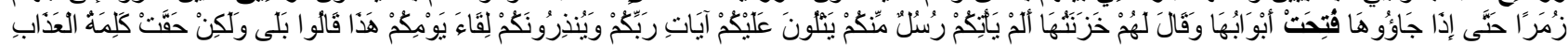

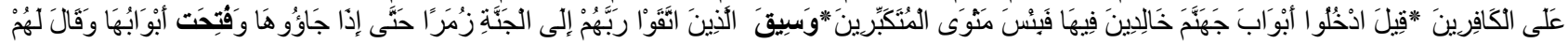

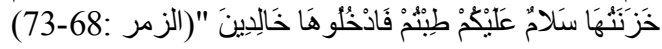

"The Trumpet will (just )be sounded, when all that are in the heavens and on earth will swoon, except such as it will please Allah (to exempt). Then will a second one be sounded when, behold, they will be standing and looking on! And the earth will shine with the light of its Lord: the record (of Deeds) will be placed (open); the prophets and the witnesses will be brought forward; and a just decision pronounced between them; and they will not be wronged (in the least). And to every soul will be paid in full (the fruit) of its deeds; and (Allah) knowth best all that they do. The unbelievers will be led to Hell in groups: until, when they arrive there, its gates will be opened. And its keepers will say, "Did not messengers come to you from among yourselves, "rehearsing to you the signs of your Lord, and warning you of the Meeting of this Day of yours? The answer will be:"true: but the decree of chastisement has been proved true against the unbelievers!" (To them) will be said: "Enter ye the gates of Hell, to dwell therein: And evil is (this) abode of the arrogant!" And those who feared their Lord will be led to the Gardens in groups: until behold, they arrive there; its gates will be opened and its keepers will say: "Please be upon you! Well have you done! Enter ye here, to dwell therein."(Al- Zumar: 68-73)

10. Linguistic context and versification.

Both active and passive forms are frequently used in the Quranic discourse, both in its linguistic context and versification.

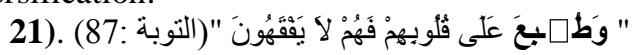

"Their hearts are sealed and so they understand not" (Al- Tawba: 87)

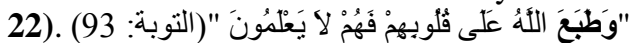

"Allah hath sealed their hearts so they know not" (Al- Tawba: 93)

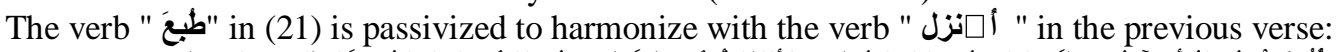

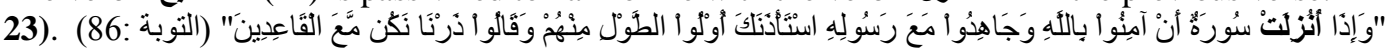

"When a sura comes down, enjoying them to believe in Allah and to strive and fight along with His Messenger, those with wealth and influence among them ask thee for exemption , and say: "Leave us (behind): we would be with those who sit (at home)" (Al-Tawba: 86).

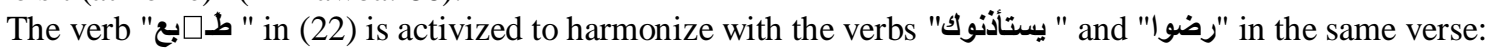

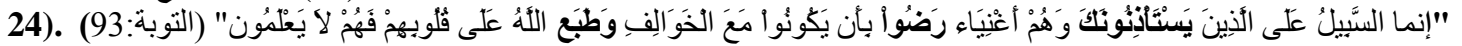

"The ground (of complaint) is only against such as claim exemption while they are rich: they prefer to stay with the (women) who remain behind: Allah hath sealed their hearts so they know not". (Al- Tawba: 93).

See (Al-Iskafi: Durar Al-Tanzīl page 719), and (Al- Zarkashi: Al -Burhan fi ؟ulum Al-Qur'an Vol .3 page 145). Moreover, the active form "طبع", when ascribed to Allah, indicates that it is stronger and becomes deep-rooted in the heart more than the passive form "طبع". See (Al-Samara'i: Balaghat Al-Kalima fi Al- Ta?bir Al - Qur'ani, P. 84).

11. Degradation / humiliation of the agent participant:

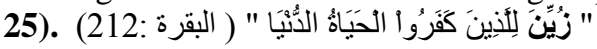

"The life of this world is alluring to those who reject faith". (Al-Baqara: 212) 
26).

"She said:" What is the (fitting) punishment for one who formed an evil design against thy wife, but prison or a grievous chastisement? "(Yusuf: 25)

The passive verb form "زئين is used to degrade satan because he is the only one who adorns or decorates the bad deeds. The active verb "زينا لهم سوء أعمالهم" (we have decorated their bad deeds for them) does not occur in the holy

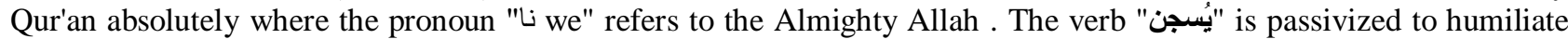
Prophet Yusuf by Zulaykha, the wife of Al- Aziz.

12. The passive is used when the agent/doer of the action is unknown or unspecified:

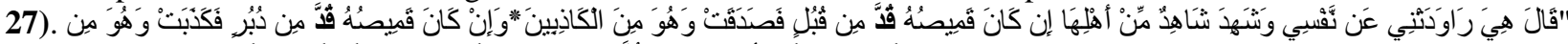

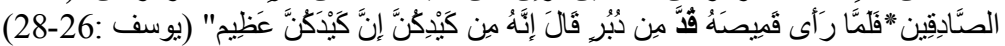

"He said: "It was she that sought to seduce me - from my (true) self". And one of her household saw (this) and bore witness, thus: "If it be that his shirt is torn from the front, then is her tale true, and he is a liar! But if it be that his shirt is torn from the back, then is she the liar, and he is telling the truth! 'So when he saw his shirt, that it was torn at the back, - her husband said: "Behold! It is a snare of you women! Truly, mighty is your sname!" (Yusuf: 26-28).

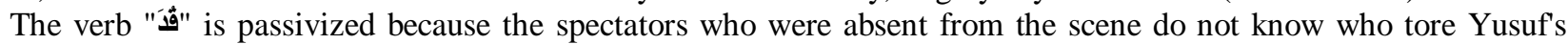
shirt .Is it Zulaikha who was in defense or is it Zulaikha who embarked boldly upon Yusuf?

28).

"When news is brought to one of them, of (the birth of) a female (child), his face darkens, and he is filled with inward grief" (Al- Nahl: 58)

It is not important for the spectators to know who brought them the bad news. The most important is the action itself.

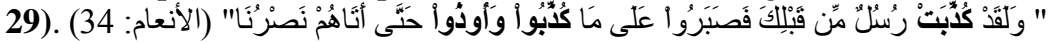

"Rejected were the Messengers before thee: with patience and constancy they bore their rejection and their persecution until our aid did reach them". (Al- An؟ām: 34)

Similarly, it is not so important to know who rejected the Messenger. The important is that they were rejected.

13. Assonance, intervals, and parallelism between sentences and succession of verb forms:

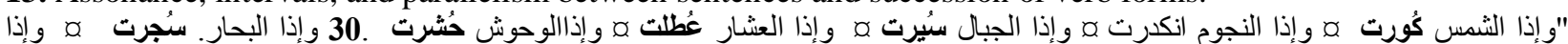

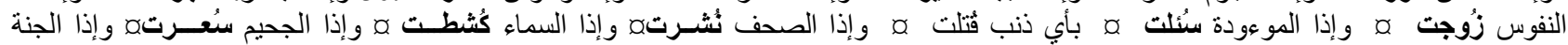

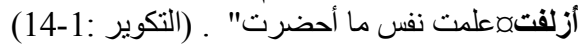

"When the sun (with its spacious light) is folded up; when the stars fall losing their luster; when the mountains vanish (like a mirage); when the she -camels, ten months with young, are left untended; when the wild beasts are herded together (in human habitations) ; when the oceans boil over with a swell; when the souls are sorted out (being joined, like with like); when the female (infant), buried alive, is questioned for what crime she was killed; when the scrolls art laid open; when the sky is unveiled; when the Blazing Fire is kindled to fierce heat; and when the Garden is brought near, then shall each soul know what it has put forward" (Al- Takwī: 1-14).

The passive verbs are all assonant and parallelised. Moreover, the intervals between them suit the verses in which these verbs are used.

14. In the Holy Qur'an the Almighty Allah ascribes good deeds to Himself, and therefore active constructions are used and the agent is overt, whereas the bad deeds are ascribed to others and passive constructions are used and the agent is covert:

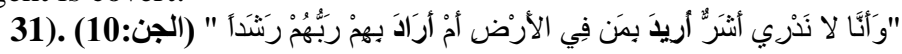

"And we understand not whether ill is intended to those on earth, or whether their Lord (really) intends to guide them to right conduct ". (Al- Jinn: 10)

32).

"We shall set up scales of justice for the Day of Judgment, so that not a soul will be dealt with unjustly in the least (Al- Anbiyā?": 47)

The verb forms" أريدَ is intended" and "نَُّ ill be dealt with unjustly" are passivized because the Almighty Allah does not ascribe the bad deeds to Himself as Allah neither intends ill or evil nor deals with people unjustly. However, sometimes the good deeds are used with passive, but in this case the active verb from are previously mentioned:

33).

"He grandth wisdom to whom he pleaseth; and he to whom wisdom is granted receiveth indeed a benefit overflowing". (Al- Baqara: 269)

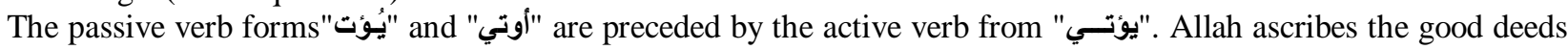
"granting wisdom" to Himself first, and then passive verb form "is granted" is used in a general sense.

15. Coloring the Quranic discourse.

Both active and passive verb forms are frequently used in the Quranic discourse but each form is used in its linguistic context. Consider the following verses:

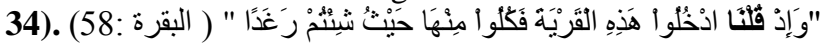

"And remember we said:"Enter this town, and eat of the plenty therein as ye wish" (Al- Baqara: 58)

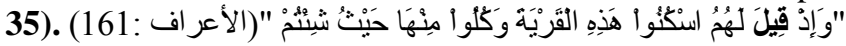

"And remember it was said to them: Dwell in this town and eat therein as ye wish". (Al- A؟rāf: 161). 
The past passive verb form (قيل) is used in (34) because it is preceded by the past active form (قنا) in (35) in which the agent is explicit .Al- Razi (Mafātih-u Al- Ghayb Vol.2, P. 92) ascribes this variety in the first context (34) to two reasons: disambiguity and the previous linguistic context, i.e. mentioning the blessings or the special favour the Almighty Allah bestowed upon Children of Israel:

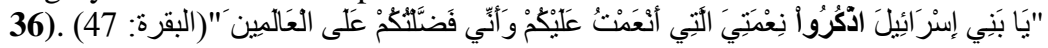

"O children of Israel! Call to mind the special favour which I bestowed upon you, and that I preferred you to all others. "(Al- Baqara: 47).

And this context suits active verb form with the overt agent, the Almighty Allah.

In the second context (35) the ambiguity is eliminated as the agent is stated previously in (34) and this suits the passive verb form. See (Al- Naysaburi: Ghra'ib Al- Qur'an Vol. 1, P. 324) and (Abu Hayyan: Al- Bahr Al- Muhit Vol. 1, P. 346)

16. Sometimes passive verb forms are used before the active forms. This refers to the fact that Arabs prefer the most important for them is what is mentioned first. See (Sibawayh : Al- Kitāb Vol.1 ,P. 15) and ( Al- Iskafi : Durat AlTanzil ,P. 1316) . Consider the following verses:

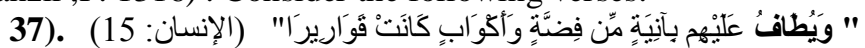

"And amongst them will be passed round vessels of silver and goblets of crystal" (Al- Insān: 15)

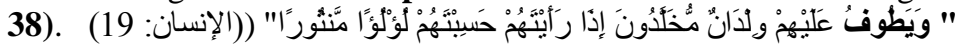

"And round about them will serve youths of perpetual (freshness). (Al-Insān: 19)

In (37) passive verb from بَطُقن is used because the most important for the audience is the description of what is

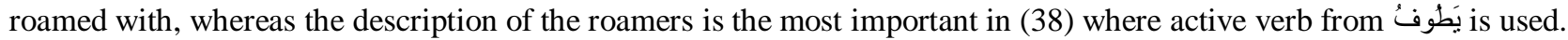

17. Passive verbs forms are used in the Holy Qur'an to show mockery / irony / sarcasm.

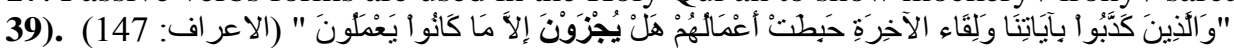

"Those who reject Our Signs and the Meeting in the Hereafter, vain are their deeds: Can they except to be rewarded except as they have wrought?" (Al- A?rāf: 147).

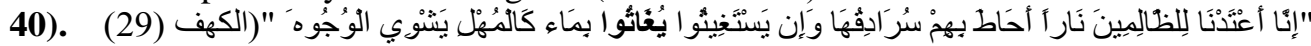

"If they (the wrong - doers) implore relief they will be granted water like melted brass that will scold their faces". (Al - Kahf: 29)

Ordinarily, the passive verb forms يُجْزون (be rewarded) in (39) and يُغاثوا (be granted) in (40) are collocationally

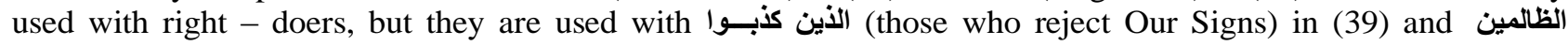
(tyrants) in (38) because they are mocked.

18. Thematization

The choice of passive is a mode of expression. That is "the notion of passive is fundamentally pragmatic" (Givon, 1990, P. 566). Since every speech event takes place in a social context, the passive offers speakers a way of "information packaging" which allows prominence to fall on participants affected by the process rather than the actors (cf. Foly and Van Valin, 1985). Thus, the passive enables the speakers to place the actor and participant affected in the structure of information in "new" and "old" slot respectively (cf .Halliday, 1994). In this context, the passive construction is, like topiclaization, a case of foregrounding which draws our attention to an element preminently placed, namely, the affected participant. (cf. Keenan, 1985, P. 243)

The passive is used when the attention of the reader / hearer is directed to the person / thing (done - to) affected by the action rather than the doer (agent) of the action i.e. preposing the "done to" to be the departure point.

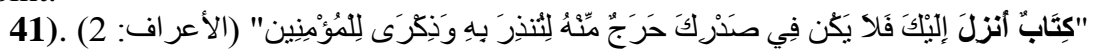

"A Book revealed unto thee, so let thy heart be oppressed no more by any difficulty on that account, that with it thou mightiest warn (the erring) and a reminder to the Believers." (Al- A?rāf: 2).

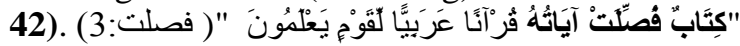

"A Book, whereof the verses are explained in details; a Qur'an in Arabic, for people who understand". (Fussilat: 3).

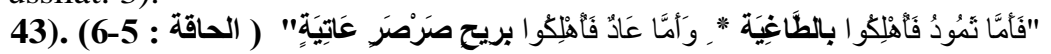

"But the Thamūd, they were destroyed by a terrible storm of thunder and lightning! And the Ad, they were destroyed by a furious wind, exceedingly violent." (Al- Hāqqa: 5-6)

19. Passive is also used when the function is not to bring the doer (agent) into view, but to highlight the action (process) itself.

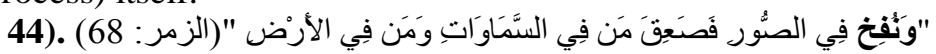
68).

"The Trumpet will (just) be sounded when all that are in the heavens and on earth will swoon". (Al- Zumar:

The action / process of (نفخ) and its terror and intensity is highlighted. It is not out of place to state what (AlAlousy, 1403, P. 266) says in his (Rouh Al- Ma؟āni fi Tafsir Al-Qur'an Al- Athim). "It is scientifically approved that the intensity of sound causes nervous tension and anger, and when it increases to reach more 200 decibel, the man will lose consciousness and die immediately.

20. Passive constructions are also used to depict the invisible / supernatural scenes of Garden and Fire in the 
Judgment Day. See (Al- Zamakhshari: Al- Kashāf Vol. 2, P. 470).

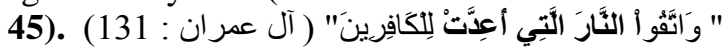

"And fear the Fire, which is prepared for those who reject Faith". (Al- Imrān: 131).

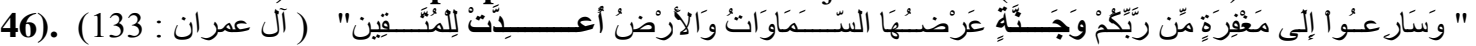

"Be quick in the race for forgiveness from your Lord and for a Garden whose width is that (of the whole) of the heavens and of the earth prepared for the righteous". (Al- Imrān: 133)

The passive verb form (أعد) أجنة الجد (Garden) is used when the Almighty Allah talks about (النار (Hell) with

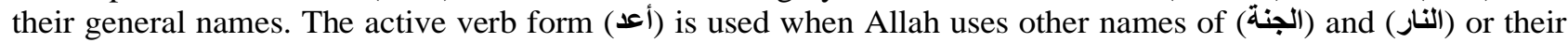
properties or their signs / meanings or indications.

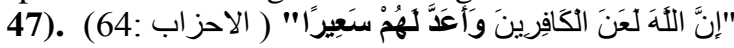

"Verily Allah has cursed the unbelievers and prepared for them a Blazing Fire" (Al- Aћzāb: 64).

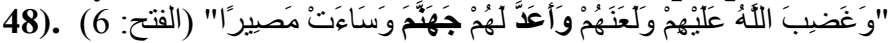

"The Wrath of Allah is on them: He has cursed them and got Hell ready for them, and evil is it for a destination". (Al- Fath: 6)

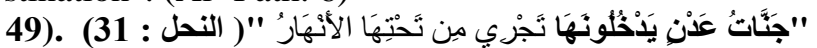

"Gardens of Eternity which they will enter: beneath them flow (pleasant) rivers". (Al- Nahl: 31).

50).

"And caused their people to descend to the House of Prediction" (Ibrāhīm: 28).

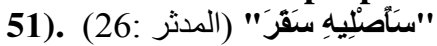

"Soon I will cast him into Hell - Fire!" (Al-Muddaththir: 26)

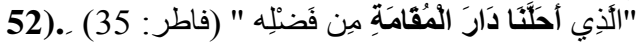

"Who has, out of His Bounty, settled us in a Home that will last". (Fatir: 35)

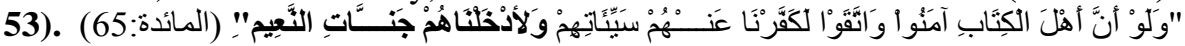

"If only the People of the Book had believed and been righteous, We shall indeed have blotted out their iniquities and admitted them to Garden of Bliss" (Al- Ma?ida: 65)

21. Passive is used to indicate generalization of religious matters / laws.

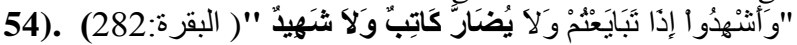

"But take witnesses whenever ye make a commercial contract; and neither scribe nor witness suffers harm". (Al- Baqara: 282).

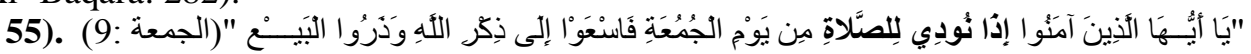

"O ye who believe! When the call is proclaimed to prayer on Friday (the Day of Assembly), hasten earnestly to the Remembrance of Allah and leave off business" (Al- Jum?a: 9).

56).

"The answer of the believers, when summoned to Allah and His Messenger, in order that He may judge between them, is no other than this: They say, "We hear and we obey." (Al- Nūr: 51).

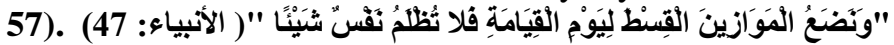

"We shall set up scales of justice for the Day of Judgment, so that not a soul will be dealt with unjustly in the least" (Al- Anbiyā?: 47)

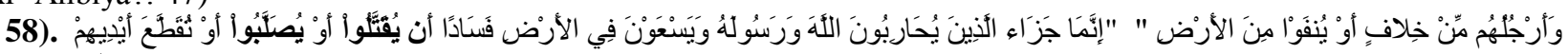
(33: (المائدة)

"The punishment of those who wage war against Allah and His Messenger, and strive with mighty and main for mischief through the land is: execution, or crucifixion, or the cutting off of hands and feet from opposite sides, or exile from the land." (Al- Ma?ida : 33).

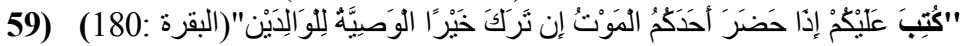

"It is prescribed, when death approaches any of you, if he leave any goods, that he make a bequest to parents and next of kin "(Al- Baqara: 180).

In the above verses neither scribe nor witness (whoever they are) should suffer harm, the Believers, (whoever they are) and (whoever the caller is) should leave off business and hasten to Remembrance of Allah, the Believers (whoever they are), when summoned to Allah and His Messenger should say "We hear and obey", no one (whoever he is) will be dealt with unjustly, those who wage war against Allah and His Messenger (whoever they are) should be punished through execution, or crucifixion, or the cutting off hands and feet from opposite sides or exile from the land, and it is prescribed to you (whoever you are) when death approaches, you should make a bequest to parents and next of kin.

22. Passive constructions are used for Allah to express His disapproval, criticism, reprimand, dispraise and blame. The following are illustrative examples:

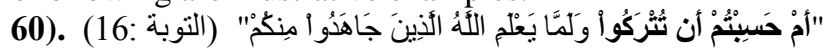

"Do you think that you would be left alone while Allah has not yet known those among you who strive with might and main" (Al- Tawba:16)

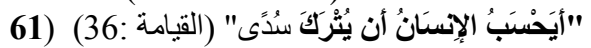

"Does Man think that he will be left uncontrolled, (without purpose)?" (Al- Qiyāma: 36) 


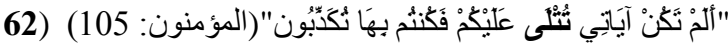

"Were not My Signs rehearsed to you, and ye did but treat them as falsehoods" ? (Al- Mu?minūn :105).

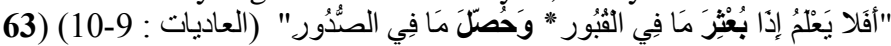

"Does he not know and that which is (locked up)in (human) breast is made manifest when that which is in the graves is scattered aboard?" (Al- ؟adiyat: 9-10).

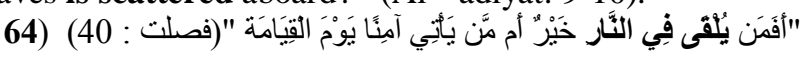

"Which is better? - he that he is cast in the fire, or he that comes safe through, on the Day of Judgment" (Fusilat: 40).

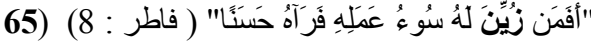

"Is he, then, to whom the evil of his conduct is made alluring, so that he looks upon it". (Fātir: 8).

23. Passive is used in the Holy Qur'an in supplication and curse.

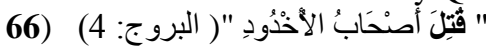

"Woe to the makers of the bit (of fire)". (Al- Burūj: 4).

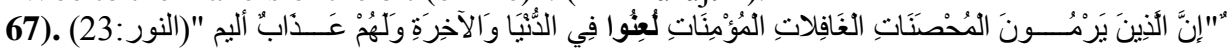

"Those who slander chaste, indiscreet and believing women are cursed in this life and in the Hereafter: for them is a grievous Chastisement." (Al- Nūr: 23)

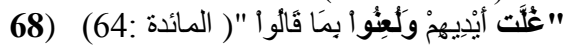

"Be their hands tied up and be they accursed for the blasphemy they utter" (Al- Mā?ida: 64).

The bold type passive verb forms in the above verses indicate either supplication or curses. See (Al- Razi: Mafatih Al- Ghayb, Vol. 6, P. 80) and (Al- Shawkāni: Fath Al- Qadir, Vol. 1, P. 83)

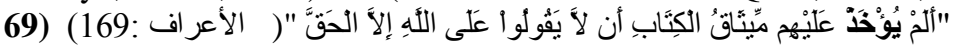

"Was not the covenant of the Book taken from them, they would not ascribe to Allah anything but the truth". (AlA 'rāf: 169)

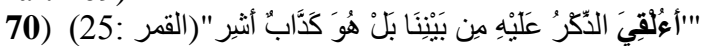

"Is it that the Messenger is sent to him, of all people amongst us? Nay, he is a liar, an insolent one?" (Al- Qamar: 25).

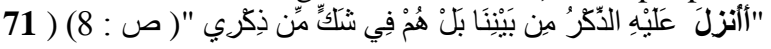

"What! Has the Messenger been sent to him - (of all persons) among us? But they are in doubt." (Sād: 8).

All passive verb forms in the above verses are in the form of interrogative sentences to indicate disapproval, criticism, reprimand or dispraise. See (Al- Zamkhashari: Al- Kashaf: Vol. 2, P. 253), (Al- Matsani Abdul Azim: Al- Tafsir AlBalāghi lil- Qur'an Al-Kareem: Vol. 2, P. 12 and Vol. 3, P. 28-29), (Ibn Kathir: Tafsir Al- Qur'an Al- Azim: Vol. 3, P. 541). Therefore, the agent is not mentioned to honor and glorify Him.

\section{Agent - focusing.}

A correlate of the morphosyntactic changes to the verb in Modern Standard Arabic is a pragmatic function "agent defocusing" (Shibantani, 1985, P, 830, Myhill, 1997). Agent defocusing in Modern Standard Arabic occurs in two ways (i) defocusing the agent to the full extent, by deleting it, or (ii) defocusing it to some degree i.e. by allowing it to show up in the prepositional phrase in the rhematic position (Agentive / long passive). Nevertheless, agent - defocusing, contrary to common beliefs, should not be understood to be a form of downgrading the agent by moving it to the end position. The following examples illustrate this point:

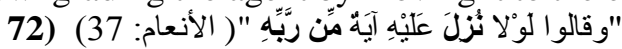

"They say "Why is not a sign sent down to him from his Lord!" (Al-An?ām: 37)

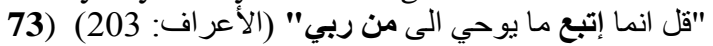

"Say: "I but follow what is revealed to me from my Lord". (Al-A?rāf: 203).

The agent "min rabbi" is presented in this verse to show that the Holy Qur'an is revealed to Mohammad from Allah, but not from anybody else.

\section{Presupposition}

Another point that is worth mentioning has to do with the pragmatic notion of presupposition. Modern Standard Arabic presupposes the process and asserts the participants. The following verse is an illustrative example:

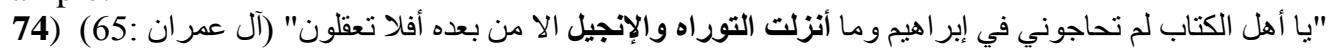

"Ye people of the book! Why dispute ye about Abraham, when the Torah and Gospel were not revealed till after him? Have ye no understanding?" (Al- Imrān: 65)

Communicatively, the above passive construction could be an answer to the question "What happened?" what is presupposed, therefore, is, in Enkrist's words (1979, P. 137), "information that the speaker (His Almighty Allah in this context) believes that the recipients of the message already have." Thus the? unzilat" (were revealed) is presented as theme and old information and "? al - tawrah" (the Torah) and? al - ?injīl" (the Gospel) counts as " new " information. Therefore, the passive form "? unzilat" (were revealed) coincides at the message, whereas the affected participant occurs as " new " within the rheme.

\section{CONCLUSION}

The facts presented in this paper demonstrate that voice is a grammatical category that exists in Arabic in general and in the Holy Qur'an in particular for certain purposes intended by the Almighty Allah. They also 
prove it is one of the options available to native speakers of Arabic to express their viewpoints, value system, beliefs and assumptions through the semantic functions used to convey certain communicative functions.

Qur'anic discourse is linguistic scenery characterized by a rainbow of syntactic, semantic and rhetoric features that are distinct from other types of Arabic prose.

Through this study we tried to investigate the semantic and stylistic functions of the passive constructions in the Holy Qur'an. Such semantic functions are sometimes similar to those stated by the grammarians and sometimes they are different.

\section{IMPLICATION}

Although this study is linguistically descriptive and is not pedagogically oriented, it may have, nonetheless, pedagogical implications for foreign language teachers, to diagnose and remedy the difficulties their students may encounter, translators, textbook writers, test makers, as well as syllabus designers.

Moreover, this study may be of great help to ESP practitioners, who are interested in preparing ESP teaching materials based on the analysis of this authentic text (The Holy Qur'an) and concerned with the semantic functions and meanings which are conveyed by the syntactic passive structures.

\section{REFERENCES}

[1] Al -Alousi, M. (1403). Rūh Al- Mạāni fĩ Tafsīr Al- Qurān Al- Athīm, Dār Al- Turāth - Cairo.

[2] Al-Ashmoni, A. (1955) Sharh Al- Ashmoni. Maktabat Al-Nahdha Al- Missriyyah - Egypt.

[3] Al -Iskafi, M. (1422). Durāt Al- Tanzīl wa Ghurat Al - Ta?wīl. Um Al- Qurā University - Mecca.

[4] Al- Mallah, Y. (1989). "Masā'l fi-Al-Mabni lil - Majhul". Bethehem University Journal, VOL. 7, 8, 83-103.

[5] Al -Naysabouri, N. (1381). Gharā?ib Al-Qur'an. Mustafa Al-Halabi Press - Egypt.

[6] Al- Razi, F. (1993). "MaFātih-u Al-Ghayb. Dār Al- Ghad Al- Arabi - Cairo.

[7] Al- Sāmarrā'i, I. (1980). Al - Fị̂1: Zamānuh wa Abniyatuh - Mu'ssasat Al- Risalah - Amman.

[8] Al- Soyouti. J. (1996). Al - Itqān fi ؟ulūm Al- Qur'an. Dār Al- Fikr - Lebanon.

[9] Al- Shawakani, M. (1997). Fath Al- Qadīr. Dār Al- Wafā? - Al-Mansoura.

[10] Al -Zarkashi, M. (1972). Al- Burhān fị ؟uūm? al- Qurān .Al- Maktab Al- Asriya. Beirut- Lebanon.

[11] Al-Zamakhshari Abu Al-Qasim, M. (1987). Al- Kashaf. Dār Al-Rayyan - Cairo.

[12] Abu Hayyan, Al-Andalusi. (1412) Al-Bahr Al-Muhīt. Dār Al-Fikr - Beirut.

[13] Allen, V.F. (1983). "A New Look at the Passive" English Teaching Forum, VOL. 21, NO.2 PP.8-11.

[14] Celce -Murcia, M. and Drane Larsen - Freeman. (1983). The Grammar Book: An ESL/ EFL Teacher's Course Rowley, Mass, Newbury House.

[15] Corray, M. (1967). "The English Passive Voice" ELT VOL, 21, NO.3, PP.203-10.

[16] Enkrist, Nils Eric. (1979). "Marked Focus: Functions and Constraints." In: S.Greenbaum, G.Leech, J.Svartvik (ed), Studies in English Linguistics for Randolph Quirk. London and New York: Longman, 134-152.

[17] Foley, William A. and Robert D. Van Valin, Jr. (1985). "Information Packaging in the Clause" In: T. Shopen (ed.), Language Typology and Syntactic Structure. Cambridge: C.U.P., 281-364.

[18] Givon, Talmy (1990). "Voice and De - transitivization". Syntax: A Functional Typological Introduction (Vol II). Amsterdam: John Benjamins, 563 - 644.

[19] Halliday, M.A.K. (1994). An Introduction to Functional Grammar (2 ${ }^{\text {nd }}$ ed $)$. London: Edward Arnold.

[20] Hasan, A. (1975). Al-Nahw-Al- Wāfi. Dār Al Ma'ārif- Misr-Cairo.

[21] Holy Qur'an -English Translation of the Meanings and Commentary- Revised and Edited by the Presidency of Islamic Researches, Ifta', Call and Guidance- King Fahd Holy Qur'an Printing Complex-Al-Madinah Al- Munawarah (1404) A. H.

[22] Huddleston, R.D. (1971). The Sentences in Written English: A Syntactic Study Based on an Analysis of Scientific Texts. Cambridge University Press. London.

[23] Huddleston, R.D. (1984). Introduction to the Grammar of English. Cambridge University Press. London.

[24] Ibn Al- Qayyim Al-Jawziyya. Sh. (2003). Al-Fawā?id Al- Mushawiqa. Al- Maktabah Al- Asriya. Beirut. Lebanon.

[25] Ibn Aqil, A. (1972). Sharh-u Ibn Agil, VOL-1, Dār Al-Fikr.Al-Arabi-Beirut.

[26] Ibn Hisham. A. (1979). Awdah Al- Masalik.Vol. 2, Dār' Al-Turath Al-Arabi-Beirut.

[27] Ibn Jinny, Abu AL-fath, O. (1998). Al-Muћtasib. Dār Al-Kutub Al-@ilmiyya-Cairo.

[28] Ibn Usfur. (1980). Sharh Jumal Al-Zajjaji. Vol. 1, Mu'ssasat Da:r Al-Kita:b, Musil University - Iraq.

[29] Ibn Ya'ish, M. (no date). Sharh Al- Mufasal. Al-Muniriyyah Press.

[30] Jesperson, O. (1933). Essentials of English Grammar. George Allen and Unwin. Ltd- London.

[31] Jesperson, O. (1951). The Philosophy of Grammar. George Allen and Unwin. Ltd- London.

[32] Khalil, A. (1989). "The Passive Voice in English and Classical Arabic: Formation, Type and Function". Bethlehem University Journal, Vol.7, PP.7-38.

[33] Keenan, Edward L. (1985). "Passive in the Worlds' Languages". In: T. Shopen (ed.), Language Typology and Syntactic Structure. Cambridge: C.U.P., 243-281.

[34] Leech, G. and J. Svartvik. (1975). A Communicative Grammar of English. Longman Group Ltd-London.

[35] Maghalesh, M.H. (2007). Al-Nahwa Al- Shāfi Dār Al-Masira Press -Amman, Jordan.

[36] Myhill, John. (1997). "Pragmatic and Categorial Correlates of VS Word Order." Lingua 66, 177-200.

[37] Palmer, F.R. (1965). A Linguistic Study of the English Verb. Longman, Green and Co Ltd. London.

[38] Quirk .et.al. (1972). A Grammar of Contemporary English. Longman Group Ltd-London.

[39] Quirk .et.al. (1985). A Comprehensive Grammar of the English Language. Longman Group Ltd-London. 
[40] Shabanah, H .M. (1981). "The Passive Sentence in Arabic", MA. Dissertation, University of Jordan.

[41] Shibantani, Masayosha. (1985). "Passive and Related Constructions: A Prototype Analysis" Language, 61:4, 821-848.

[42] Sibawayhi Abu Bashir,O. (1985). Al-Kitaab,Dār Al-?ilm Al-Arabiyya. Beirut.

[43] Thompson, A .J. and A.V. Martinet. (1960). A Practical English Grammar. Oxford University - Oxford.

[44] Van Ek, J. and R. Nico. (1984). The Students Grammar of English. Basil Blackwell Ltd. - Oxford.

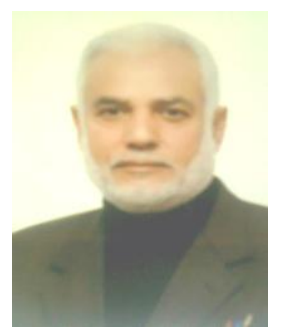

Khalil Hassan Nofal obtained his Ph.D from Jordan University in 2002. He occupied some educational, administrative and academic posts: School Supervisor (English), EDC, Administration Officer, and General Education Specialists / UNRWA - UNESCO. He has been working as chair / Department of English and Director/ Language Centre - Philadelphia University- Jordan. He is Editorial Board member in (IJSST), (IER), and (EJBSS) and APETAU member. 